Abstract

\title{
Soil Erosion in Endangered Chestnut Tree Farms of Rural Areas (Navezuelas, Cáceres, Spain) ${ }^{\dagger}$
}

\author{
Manuel Pulido Fernández 1,* , Artemi Cerdà ${ }^{2}$, Jesús Barrena González ${ }^{1}$, Susanne Schnabel ${ }^{1}$ and \\ Mohamed Amine Abdennour ${ }^{3}$ \\ 1 GeoEnvironmental Research Group, Department of Arts and Territory Sciences, University of \\ Extremadura, Avda de la Universidad, s/n, 10071 Cáceres, Spain; jesusbarrena@unex.es (J.B.G.); \\ schnabel@unex.es (S.S.) \\ 2 Soil Erosion and Degradation Research Group, Department of Geography, Valencia University, Blasco \\ Ibàñez, 28, 46010 Valencia, Spain; artemio.cerda@uv.es \\ 3 Laboratory of ecosystem diversity and agricultural production system dynamics in arid zones \\ (DEDSPAZA), Faculty of Natural Sciences and Life, Agronomy Department, University of Mohamed \\ Khider of Biskra, Biskra 07000, Algeria; abdennourmohamedamine@gmail.com \\ * Correspondence: mapulidof@unex.es \\ † Presented at TERRAenVISION 2019, Barcelona, Spain, 2-7 September 2019.
}

Published: 20 December 2019

\begin{abstract}
The municipality of Navezuelas (Cáceres, Spain) is regionally known for the cultivation of chestnut trees on steep slopes, which form a landscape of bocage dominated by small farms (family property). Nowadays, this traditional system is endangered, on one hand, as consequence of ageing, depopulation and land abandonment, and on the other hand, due to the reduction of rainfall, tree diseases and changes in land management that are provoking land degradation processes little studied so far. Soil erosion is probably the most important process since farmers need to keep large patches of bare soil (particularly beneath the trees) in autumn in order to facilitate the collection of chestnuts from the ground. Therefore, the main goal of this research was to study soil erosion in chestnut tree farms aimed at verifying whether it is a remarkable process. To achieve this goal, 18 erosion plots $\left(\approx 2 \mathrm{~m}^{2}\right.$ in size) were installed to quantify soil and water losses in paired plots (open vs. tree) within a farm of 5 ha with chestnut trees planted in different times (1960s vs. 1990s). Total rainfall per event, runoff coefficient, the percentage of bare soil and tree cover and the concentration of sediments were quantified after each significant event in each plot during the whole hydrologic year 2017/2018. The results showed average values of bare soil above $50 \%$ during the harvesting (October-November) and above $40 \%$ in winter when sheep were introduced to eat the remains of the harvest. Tree cover followed a natural cycle of deciduous trees excepting an occasional pruning. Regarding soil erosion the highest rates were observed in open spaces within the part of the farm with younger trees (av. $57.1 \mathrm{~g} \mathrm{~m}^{-2} \mathrm{yr}^{-1}$, range: $35.6-87.3 \mathrm{~g} \mathrm{~m}^{-2} \mathrm{yr}^{-2}$ ) and the lowest one beneath the trees within the part with older trees (av. $3.4 \mathrm{~g} \mathrm{~m}^{-2} \mathrm{yr}^{-2}$, range: $0.4-22.7 \mathrm{~g} \mathrm{~m}^{-2} \mathrm{yr}^{-2}$ ). In fact, the highest single valued quantified was $67.2 \mathrm{~g} \mathrm{~m}^{-2}$ in an event of $37.51 \mathrm{~m} \mathrm{~m}^{-2}$ in October $(\approx 100 \%$ bare soil). Obviously, these erosion rates were positively correlated with the runoff coefficient (r: $0.755, p<0.001$ ) that averaged $8.5 \%$ in the open spaces near the youngest trees. Our findings suggest soil erosion is not a problematic process yet in Navezuelas and confirm the protector effect of trees avoiding soil erosion. Nevertheless, they are only preliminary results measured during a relative dry year $\left(626.91 \mathrm{~m}^{-2}, \approx 60 \%\right.$ out of a normal year).
\end{abstract}


Keywords: Traditional farming; Sustainability; Las Villuercas

(C) 2019 by the authors. Licensee MDPI, Basel, Switzerland. This article is an open access article distributed under the terms and conditions of the Creative Commons Attribution (CC BY) license (http://creativecommons.org/licenses/by/4.0/). 